\title{
KONSEP BERPIKIR SISTEMIK DALAM PENYUSUNAN RENCANA STRATEGIS
}

Fakhrurrazi

Institut Agama Islam Negeri Langsa

frazilgs@yahoo.com

\begin{abstract}
ABSTRAK
Pendidikan merupakan sebuah program yang terencana dan tersistem dengan baik. Program yang melibatkan sejumlah komponen yang bekerjasama dalam sebuah proses untuk mencapai tujuan yang diprogramkan. Berpikir untuk mencari dan melihat segala sesuatu memiliki pola keteraturan dan bekerja sebagai sebuah sistem. Rencana strategis sangat penting sehingga harus dirancang sendiri oleh masing-masing organisasi dengan memperhitungkan kondisi nyata dan sumber daya yang dimiliki, untuk menjadi landasan dan pedoman kerja bagi setiap pegawai dalam menjalankan tugas dan fungsinya. Metode yang digunakan dalam penulisan ini adalah dengan studi kepustakaan. Studi kepustakaan merupakan penelitian yang menjadikan data-data kepustakaan sebagai teori untuk dikaji dan ditelaah dalam memperoleh hipotesis atau konsepsi untuk mendapatkan hasil yang objektif.
\end{abstract}

Kata kunci: konsep, berfikir sistemik, rencana strategis

\section{ABSTRACT}

Education is a program that is well planned and systemized. Programs that involve a number of components that work together in a process to achieve the programmed goals. Thinking to look for and see everything has a regular pattern and works as a system. The strategic plan is very important so that it must be designed individually by each organization by taking into account the real conditions and resources owned, to become the basis and work guidelines for each employee in carrying out their duties and functions. The method used in this paper is a literature study. Literature study is research that uses library data as a theory to be studied and analyzed in obtaining a "hypothesis or conception to obtain objective results."

Key Words: concepts, systemic thinking, strategic planning

\section{PENDAHULUAN}

Pendidikan merupakan sebuah program yang terencana dan tersistem dengan baik. Program yang melibatkan sejumlah komponen yang bekerjasama dalam sebuah proses untuk mencapai tujuan yang diprogramkan. Sebagai sebuah program, pendidikan merupakan aktivitas sadar dan sengaja yang diarahkan untuk mencapai suatu tujuan (Purwanto, 2009, p. 1). Sebagai sebuah 
upaya bersama dari beberapa komponen yang ada, pengelolaan sistem kelembagaan tidak dapat lepas dari konsep-konsep manajemen maupun administrasi yang baik.

Rencana strategis (Renstra) merupakan komponen penting dalam manajemen sebuah organisasi (Kementerian/Lembaga/Perangkat Daerah dan Sekolah) karena menjadi panduan dan pedoman dalam memberikan pelayanan kepada masyarakat dan stakeholder. Rencana tersebut disusun dan dilaksanakan oleh para manajer puncak dan menengah untuk mencapai tujuan organisasi yang lebih luas. Untuk itu dalam penerapannya di dalam sebuah organisasi, pejabat tertinggi perlu membuat suatu perencanaan strategis yang mana dikoordinasi dengan para pegawai untuk dijalankan bersama demi mencapai tujuan yang diinginkan dari sebuah organisasi.

Rencana strategis sangat penting sehingga harus dirancang sendiri oleh masing-masing organisasi dengan memperhitungkan kondisi nyata dan sumber daya yang dimiliki, untuk menjadi landasan dan pedoman kerja bagi setiap pegawai dalam menjalankan tugas dan fungsinya.

Perencanaan dan implementasi strategi pada lembaga pendidikan, merupakan kerangka kerja pengembangan dalam kurun waktu yang cukup panjang, berkisar antara 3 sampai dengan 10 tahun (James, 1983, p. 9). Berfikir untuk sebuah perencanaan jangka panjang (strategis) seperti ini, merupakan hal yang tidak gampang, seringkali kita akan dihadapkan pada persoalan yang rumit dalam menangkap isu-isu strategis yang ada, terlebih lagi dalam memprediksi masa depan. Sejalan dengan itu, dalam memprediksi masa depan, terdapat tiga asumsi dasar yang harus dijadikan landasan, diantaranya adalah masa depan akan berbeda dengan masa lalu, masa depan akan lebih sulit untuk diprediksi, dan tingkat perubahannya akan lebih cepat dibanding sebelumnya (James, 1983, pp. 3-4). Sehingga, untuk dapat melakukan prediksi dan analisa terkait masa depan, seorang pemimpin lembaga pendidikan perlu berfikir strategis dan berencana strategis. Perencanaan dan berfikir strategis pada dasarnya tidak sama, namun keduanya sangat dibutuhkan dalam keseluruhan proses menuju kesuksesan (Luxton, 2005, p. 9).

Sistem pendidikan merupakan suatu sistem yang terbuka, sebagai suatu sistem yang bersifat terbuka sistem pendidikan ditandai dengan adanya struktur sistem pendidikan yang terdiri atas sistem pendidikan yang bersifat nasional, sub sistem pendidikan yang terdiri atas pendidikan sekolah dan pendidikan diluar sekolah, komponen pendidikan yang terdiri atas pendidikan dasar, pendidikan menengah, dan pendidikan tinggi, sub komponen yang terdiri atas pendidikan umum, pendidikan kejuruan, pendidikan keagamaan, dimensi fasilitas dan pembiayaan pendidikan, variabel pendidikan yang terdiri atas jumlah peserta didik, jumlah tenaga pendidik, sarana dan prasarana pendidikan serta penanggung jawab pendidikan yang terdiri atas orang tua, masyarakat dan pemerintah.

Sebagai suatu sistem terbuka, sistem pendidikan melalui hubungan internal dan eksternal. Hubungan internal dalam sistem pendidikan ditandai dengan adanya hubungan yang suksesif, antara satu jenjang pendidikan dengan jejang yang lainnya. Sedangkan hubungan eksternal ditandai adanya interaksi, interelasi, interdependensi antara sistem pendidikan dengan pendidikan yang lainnya yang berada diluar sistem pendidikan. 
Salah satu konsep dasar yang juga ditemui oleh sistem pendidikan, yaitu konsep entropy, konsep ini berkaitan denagn konsep keseimbangan dinamik. Yang dimaksud dengan konsep keseimbangan dinamik adalah kemampuan, ketangguhan, dan keseimbangan dinamik dari suatu sistem dalam mempertahankan eksistensinya. Dalam sistem pendidikan wujud konsep keseimbangan dinamik ini tercantum kedalam berbagai peraturan perundangundangan yang mengatur hubungan antara berbagai subsistem, komponen, dan subkomponen serta antara dimensi yang satu dengan dimensi yang lainnya dalam suatu sistem pendidikan (Utsman \& Nadhirin, 2008, p. 66).

\section{METODE}

Metode yang digunakan dalam penulisan ini adalah dengan studi kepustakaan. Studi kepustakaan merupakan penelitian yang menjadikan datadata kepustakaan sebagai teori untuk dikaji dan ditelaah dalam memperoleh hipotesis atau konsepsi untuk mendapatkan hasil yang objektif. Dengan jenis ini informasi dapat diambil secara lengkap untuk menentukan tindakan ilmiah dalam penelitian sebagai instrument penelitian memenuhi standar penunjang penelitian (Subagyo, 2015). Sumber datanya diperoleh dari buku, artikel jurnal, prosiding, dan hasil penelitian lainnya yang berkaitan.

\section{HASIL DAN PEMBAHASAN \\ Berfikir Sistemik}

Berpikir sistemik (systemic thinking) adalah sebuah cara untuk memahami sistem yang kompleks dengan analisis bagian-bagian sistem tersebut untuk kemudian mengetahui pola hubungan yang terdapat di dalam setiap unsur atau eleman penyusun sistem tersebut pada prinsipnya berpikir sistemik mengkombinasikan dua kemampuan berpikir yaitu, kemampuan berpikir analis dan berpikir sintesis (Aminullah, 2004, p. 2).

Berpikir sistematik (systematic thiking) artinya memikirkan segala sesuatu berdasarkan kerangka metode tertentu, ada urutan dan proses pengambilan keputusan. Disini diperlukan ketaatan dan kedisiplinan terhadap proses dan metoda yang hendak dipakai. Metoda berpikir yang berbeda akan menghasilkan kesimpulan yang beda, namun semuanya dapat dipertanggungjawabkan karena sesuai dengan proses yang diakui luas.

Berpikir sistemik (systemic thinking) maknanya mencari dan melihat segala sesuatu memiliki pola keteraturan dan bekerja sebagai sebuah sistem. Sementara berpikir sistemik adalah menyadari bahwa segala sesuatu berinteraksi dengan pikiran lain disekelilingnya, meskipun secara formal procsedural mungkin tidak terkait langsung atau secara spesial berada diluar lingkungan tertentu. Systemic thinking lebih menekankan pada kesadaran bahwa segala sesuatu berhubungan dalam satu rangkaian sistem. Cara berpikir seperti berseberangan dengan berpikir fragmented linear cartesian.

Syarat awal untuk memulai adanya kesadaran untuk menghormati dan memikirkan suatu kejadian sebagai sebuah sistem. Penggunaan bahasa sistem dalam berpikir dapat mendapatkan berbagai penafsiran sistem dari obyek yang sama. Perbedaan penafsiran terletak pada sudut pandang yang dipakai dalam memikirkan suatu kejadian yang sama sebagai suatu system. Untuk memudahkan jalannya berpikir sistemik, penetapan tujuan dari sistem 
dinyatakan dalam bentuk yang lebih nyata, yaitu kinerja sistem yang teramati sebagai capaian hasil kerja dari sistem. Kinerja sistem yang teramati adalah muara dari rangkaian kejadian dalam sistem, baik sistem fisik maupun sistem nonfisik. Ringkasnya, kinerja sistem berkaitan dengan kerja dari keseluruhan unsur sistem yang saling berpengaruh dalam batas lingkungan tertentu. Jadi suatu sistem dapat saja menjadi suatu sistem yang lebih kompleks, yang berarti bahwa kita yang mempertimbangkannya sebagai sistem, dan kita sendiri yang menentukan batas-batas dari sistem itu sendiri (Aminullah, 2004, pp. 3-5).

Banyak para ahli pendidikan mengatakan bahwa pendidikan adalah merupakan sistem tebuka (open system). Artinya proses pendidikan sangat ditentukan oleh perkembangan atau dinamika perkembangan dari luar pendidikan. Oleh sebab itu pendidikan harus mampu merespon perkembangan dan dinamika yang ada diluar pendidikan misalnya dinamika budaya, sosial, tekhnologi dan politik.

Inti pendidikan adalah pembelajaran, dengan demikian pembelajaran juga merupakan sebuah sistem terbuka yang dipengaruhi oleh sesuatu yang ada diluar pembelajaran, seperti ideologi guru, kompetensi guru, kualifikasi personal siswa, kelengkapan sarana, kebijakan politik dan tekhnologi informasi. Berdasarkan asumsi ini maka sistem dalam pembelajaran perlu di desain secara utuh dan komprehensif agar proses pembelajaran benar-benar sesuai idealisme yaitu mampu memberdayakan potensi siswa sehingga menjadi manusia yang utuh baik dalam aspek kognitif (kualitas intelektual), affektif (kualitas kepribadian), kualitas psikomotorik yaitu ketrampilan otot atau mekanik (Sarbini, 2011, pp. 17-18).

Berpikir sistem berarti berpikir terhadap suatu objek secara utuh, keberhasilan atau kegagalan lebih disebabkan oleh banyak elemen atau faktor. Menghilangkan salah satu elemen berarti menghambat percepatan untuk mencapai kualitas sebuah produk.

Berpikir sistem dapat juga disamakan dengan berpikir logis. Pola berpikir logis ini sering ditunjukkan dalam bentuk model pembelajaran. Menurut Kaufman model berpikir sistem yang diambil dari manajemen pendidikan dapat dirumuskan sebagai proses enam tahap yang meliputi pertama yaitu identifikasi prioritas kebutuhan dan masalah yang berkaitan. Kedua yaitu menentukan persyaratan untuk memecahkan persoalan serta identifikasi alternatif pemecahan yang mungkin dilaksanakan untuk memenuhi kebutuhan tertentu. Ketiga yaitu pemikiran alternatif atau penentuan strategi pemecahan berdasarkan alternatif yang dimungkinkan. Keempat adalah pelaksanaan strategi yang dipilih, termasuk manajemen dan kontrol atas strategi tersebut. Kelima adalah penilaian keefektifan hasil karya berdasarkan kebutuhan dan persyaratan yang telah ditetapkan terlebih dahulu. Serta keenam adalah penyempurnaan satu atau keseluruhan langkah dimuka umtuk menjamin bahwa sistem pendidikan itu bersifat responsif, efektif, dan efisien. Seluruh tahapan tersebut dapat dijadikan landasan dalam menyelesaikan atau memecahkan permasalahan yang ada dalam proses pendidikan juga dapat diaplikasikan dalam proses pembelajaran (Sarbini, 2011, pp. 19-20).

Berpikir sistemik dalam pembelajaran adalah proses berpikir yang didasarkan pada masalah pembelajaran sebagai suatu keseluruhan secara tuntas dan dapat mendalami pula bagian-bagiannya. Ciri utama pembelajaran 
adalah adanya interaksi. Interaksi yang terjadi antara siswa dengan lingkungan belajarnya, baik itu guru, teman, alat, media pembelajaran, dan sumber-sumber belajar yang lain. Sedangkan ciri-ciri lainnya dari pembelajaran ini berkaitan dengan komponen-komponen sistem pembelajaran itu sendiri. Dimana dalam pembelajaran akan terdapat komponen-komponen berupa tujuan, bahan/materi, strategi, media, dan evaluasi pembelajaran. Sebagai suatu sistem, pembelajaran akan dipengaruhi oleh beberapa unsur yang membentuknya. Beberapa unsur yang dapat mempengaruhi kegiatan proses pembelajaran diantaranya guru, siswa, sarana, alat dan media, dan lingkungan. Manfaat berpikir sistemik dalam pembelajaran diantaranya adalah dengan berpikir sistemik dalam pembelajaran maka arah dan tujuan pembelajaran dapat direncanakan dengan jelas, menuntun guru pada kegiatan yang sistematis, dengan berpikir sistemik dalam pembelajaran, kita akan diarahkan untuk melihat suatu permasalahan sebagai bagian dari suatu sistem secara luas dan bukan sebagai suatu bagian spesifik yang terpisah.

\section{Rencana Strategis (Renstra)}

Perencanaan strategi atau strategic planning terdiri dari kata yaitu perencanaan (planning) dan strategis (strategic). Perencanaan strategis adalah proses formal yang di desain untuk membantu suatu organisasi dalam mempertahankan posisi yang optimal dengan berbagai elemen penting dari lingkungan tersebut (Rowley et al., 1997, p. 15). Pendapat lainnya terkait perencanaan strategi adalah kumpulan keputusan dan tindakan yang menghasilkan formulasi dan implementasi dari rencana yang dirancang untuk mencapai tujuan suatu organisasi, lembaga dan perusahaan. Strategi menjelaskan pengertian suatu lembaga tentang bagaimana, kapan dan dimana lembaga tersebut berkompetisi, terhadap siapa lembaga tersebut berkompetisi dan untuk tujuan apa lembaga tersebut berkompetisi (Pearce \& Robinson, 2009, p. 3).

Perencanaan strategis salah satu proses penyusunan jangka panjang yang sangat diperlukan (Kodrat, 2009, p. 120). Perencanaan strategis salah satu proses penyusunan jangka panjang yang sangat diperlukan. Koontz dan Weihrich meyatakan bahwa di dalam organisasi modern, perencanaan (planning) merupakan salah satu fungsi manajemen. Di samping fungsi manajemen lainnya, yaitu pengorganisasian (organizing), penyusunan staff (staffing), memimpin (leading) dan pengendalian (controlling) (Solihin, 2012, p. 4).

Adapun pencapaian keberhasilan tujuan yang dicapai, perlu adanya langkah-langkah perencanaan strategis. Terdapat dua teori terkait langkahlangkah perencanaan strategis, yaitu teori Bryson dan teori Jhon A. Pearce II. Dalam teori Bryson tentang penyusunan perencanaan strategis derdiri dari lima langkah, yaitu yang pertama adalah penetapan visi, misi dan tujuan organisasi, yang merupakan tindakan mengembangkan dan mengklarifikasikan tanggung jawab sosial dari perusahaan yang berkaitan dengan pernyataan visi, misi dan tujuan organisasi untuk mencapai tujuan dari organisasi. Langkah kedua adalah analisis lingkungan eksternal, yaitu mengungkapkan lingkungan luar yang dimaksud untuk mengidentifikasi peluang dan ancaman yang dihadapi oleh lembaga atau perusahaan, berkaitan dengan faktor politik, ekonomi, sosial. Arah perkembangan teknologi merupakan bagian dari aktivitas analisis luar. Langkah 
ketiga adalah analisis lingkungan internal, yaitu merupakan langkah yang digunakan utuk menganalisis ke dalam organisasi itu sendiri, dengan menilai sumberdaya organisasi. Indikator dalam analisis lingkungan internal hanya berfokus pada kekuatan dan kelemahan organisasi itu sendiri. Langkah keempat adalah identifikasi isu-isu strategis berkaitan dengan yang dihadapi organisasi, yaitu merupakan pertanyaan-pertanyaan yang berkaitan dengan kebijakan fundamental tentang pengaruh mandat organisasi, visi, misi, pelayanan biaya, pendanaan, maupun rencana organisasi atau manajemen. Dan langkah kelima adalah mengembangkan strategi, yaitu melaksanakan tindakan-tindakan dari keputusan atas dasar isu-isu strategis yang telah diidentifikasikan pada langkah sebelumnya, untuk mengelola isu strategis dan penetapan visi organisasi yang efektif dan efesien (Nurhapna \& Haksama, 2014).

Teori kedua mengenai langkah-langkah perencanaan strategis adalah teori yang dikemukakan oleh Jhon A. Pearce II, bahwa dalam penyusunan perencanaan strategis terdiri dari 6 langkah, yaitu pertama penentuan misi dan tujuan yang merupakan tanggung jawab kunci bagi manajer puncak. Perumusan ini dipengaruhi oleh nilai-nilai yang dibawakan manajer. Langkah kedua adalah pengembangan profil perusahaan yang akan menunjukkan kesuksesan perusahaan diwaktu yang lalu dan kemampuannya untuk mendukung pelaksanaan kegiatan sebagai implementasi strategi dalam pencapaian tujuan diwaktu yang akan datang. Langkah ketiga adalah analisa lingkungan eksternal, yaitu mengidentifikasi cara-cara dalam mana perubahan-perubahan lingkungan ekonomi teknologi, sosial atau budaya, dan politik dapat secara tidak langsung mempengaruhi organisasi. Langkah keempat adalah analisa internal perusahaan, yang mana analisa ini dilakukan dengan memperbandingkan profil perusahaan dan lingkungan eksternal. Langkah kelima adalah pengembangan strategi perusahaan. Setelah tujuan jangka panjang dan strategi dipilih dan ditetapkan, organisasi perlu menjabarkannya ke dalam sasaran-sasaran jangka pendek (tahunan) dan strategi-strategi operasional. Dan langkah terakhir adalah peninjauan kembali dan evaluasi (Handoko, 2009, p. 94).

Proses perencanaan strategis membekali organisasi dengan sebuah sarana yang mengedepankan orientasi ke masa depan, menggunakan sistem pendekatan, memungkinkan untuk melakukan pengaturan goals dan strategi, memberikan kerangka umum dalam hal keputusan dan bergantung pada pengukuran kinerja (Stainer et al., 1997, p. 23). Proses perencanaan strategis atau manajemen strategis merupakan proses pengarahan usaha perencanaan strategis dan menjamin strategi tersebut dilaksanakan dengan baik sehingga menjamin kesuksesan organisasi dalam jangka panjang. Perencanaan strategis tidak mengenal standar baku, dan prosesnya mempunyai variasi yang tidak terbatas. Tiap penerapan perlu merancang variasinya sendiri sesuai kebutuhan, situasi dan kondisi setempat.

\section{Menentukan sebuah Organisasi}

Setiap organisasi perlu melakukan suatu perencanaan dan wacana dalam setiap kegiatan organisasinya, baik dalam pengembangan organisasi, program, maupun anggarannya. Perencanaan (planning) merupakan proses dasar bagi organisasi untuk memilih sasaran dan menetapkan bagaimana cara mencapainya, sedangkan rencana (plan) adalah hasil dari perencanaan 
(planning) yang di proses oleh perencana (planner). Oleh karena itu, perusahaan harus menetapkan tujuan dan sasaran yang hendak dicapai sebelum melakukan prosesproses perencanaan.

Perencanaan diperlukan dan terjadi dalam berbagai bentuk organisasi, sebab perencanaan ini merupakan proses dasar manajemen di dalam mengambil suatu keputusan dan tindakan. Perencanaan diperlukan dalam jenis kegiatan baik itu kegiatan organisasi, program maupun kegiatan di masyarakat, dan perencanaan ada dalam setiap fungsi-fungsi manajemen, karena fungsifungsi tersebut hanya dapat melaksanakan keputusan-keputusan yang telah ditetapkan dalam perencanaan.

Dalam fungsi pengorganisasian, manajer mengalokasikan keseluruhan sumber daya organisasi sesuai dengan rencana yang telah dibuat berdasarkan suatu kerangka kerja organisasi tertentu. Kerangka kerja tersebut dinamakan sebagai desain organisasi. Menurut Mintzberg dalam menciptakan suatu desain organisasi yang efektif, organisasi dibentuk dari beberapa elemen untuk menjadi suatu konfigurasi/struktur yang lebih efektif. Terdapat dua argumentasi sebagai dasar simpulan yang menyatakan konfigurasi mendorong keefektifan organisasi yaitu yang pertama adalah alamiah. Dalam hal ini lingkungan mendorong bentuk organisasi untuk melanjutkan kelangsungan hidupnya, agar terjadi efisien biaya dan dapat bersaing, sebuah organisasi harus dapat menyesuaikan diri dengan sifat struktural. Yang kedua adalah organisasi, yaitu dapat didorong ke arah konfigurasi tertentu untuk mencapai konsistensi dalam karakteristik internal organisasi sehingga cocok dengan situasi mereka (Mintzberg, 1993).

Rencana strategis organisasi merupakan elemen penting dalam pengembangan sebuah lembaga atau organisasi. Hal ini tidak terbatas pada lingkup lembaga yang berorientasi pada kegiatan nirlaba atau kemasyarakatan, tetapi juga pada organisasi berorientasi laba atau keuntungan. Organisasi secara prinsipil memiliki berbagai kesamaan meski dalam tujuan dan bentuk yang berbeda.

Penyusunan Renstra perlu dilakukan secara sistematis. Hasil dari Renstra secara berkala tentu saja dapat dievaluasi, diolah kembali atau diperbarui. Langkah yang harus ditempuh untuk ogranisasi yang akan melakukan renstra adalah menyusun misi organisasi, menyusun tujuan organisasi, menentukan sasaran (objectives), dan menyusun rencana kerja.

Misi menjadi salah satu kata kunci dalam pengembangan organisasi. Misi adalah bentuk sederhana dari keseluruhan cita-cita jangka pendek sebuah organsiasi. Misi merangkum secara terperinci berbagai aspek yang ingin dicapai sebuah organisasi pada jangka waktu yang terukur. Misi meringkas visi. Pada makna yang lain, misi menurunkan visi ke dalam kerangka ideal capaian pada jangka yang lebih dekat, pendek atau lebih mungkin dilakukan sebagai proses mencapai visi.

Tujuan organisasi adalah turunan dari misi. Jika misi menggambarkan tujuan besar pada organisasi Anda, maka tujuan memperinci dan membatasinya dalam jangka yang lebih dekat. Sama halnya dengan misi, tujuan dirumuskan dalam pernyataan. Tujuan biasanya digambarkan dalam kalimat kerja yang aktif. Meski demikian, ada beberapa pendapat yang menyatakan bahwa tujuan baiknya ditulis tidak dalam kata kerja. 
Sasaran merupakan turunan dari tujuan. Dalam satu tujuan, terdapat beberapa hal atau dimensi yang harus dicapai. Sasaran menjelaskan secara lebih terperinci apa yang dicapai pada setiap aspek. Sasaran menjembatani untuk mencapai beberapa tujuan mikro yang menghantar pada misi yang merupakan tujuan makro.

Rencana Kerja (RK) menjadi acuan rinci untuk memastikan misi, tujuan dan sasaran bisa dicapai. RK membuat rincian aktivitas yang akan dilakukan guna mencapai rincian-rincian tujuan. Rencana kerja perlu disusun untuk memastikan bahwa sebuah organisasi memiliki target spesifik dalam pencapaian. Hal ini akan memermudah proses mengevaluasi dan memantau ketercapaian tujuan, sasaran dan misi organisasi pada periode tertentu. Rencana strategis (Renstra) umumnya dikaitkan dengan sejauh mana sebuah organisasi bermimpi untuk mencapai satu tujuan. Tujuan pada konteks ini merupakan bagian dari tujuan umum pembentukan organisasi. Pada konteks ini, organisasi akan dihadapkan pada tujuan jangka pendek dan jangka panjang.

\section{Melakukan Analisis SWOT}

SWOT merupakan singkatan dari perkataan Strength (kekuatan), Weaknesses (kelemahan), Opportunities (peluang) dan Threat (ancaman). Keempat unsur ini merupakan aspek penting yang perlu dibahas untuk dapat mengetahui kondisi dan potensi yang dimiliki oleh suatu daerah atau institusi tertentu. Dengan demikian analisis SWOT dapat diartikan sebagai suatu teknik analisis yang menggunakan keempat unsur tersebut sebagai variabel utama dalam melakukan analisis. Analisis SWOT ini berasal dari IImu Manajemen (Management Scince) yang diterapkan untuk perumusan pengembangan perusahaan (Rangkuti, 1997, p. 43).

Strength (kekuatan) pada dasarnya merupakan kelebihan yang dimiliki oleh suatu daerah dan institusi dibandingkan dengan daerah dan institusi lainnya. Dalam analisis kondisi sosial ekonomi daerah kekuatan tersebut dapat muncul dalam bentuk kesuburan tanah yamg lebih baik, potensi sumberdaya alam yang lebih besar, kualitas pendidikan yang lebih baik, kondisi keuangan yang lebih mapan dan lain-lainnya. Analisis akan menjadi lebih kongkrit dan meyakinkan bilamana kekuatan ini dapat dibuktikan secara kuantitatif dengan menggunakan indikator pembangunan dan data tertentu.

Weaknesses (kelemahan) pada dasarnya merupakan kekurangan atau kelemahan yang dimiliki oleh suatu daerah atau institusi tertentu dibandingkan dengan daerah dan institusi lainnya. Dalam analisis kondisi sosial ekonomi, unsur kelemahan ini pada dasarnya merupakan kebalikan dari unsur kekuatan sebagaimana telah dijelaskan di atas. Dengan demikian kelemahan dapat muncul dalam bentuk relatif rendahnya tingkat kesuburan lahan, terbatasnya atau relatif kecilnya potensi sumberdaya alam, rendahnya kualitas sumberdaya manusia dan lain-lainnya. Sama halnya dengan unsur kekuatan, analisis tentang kelemahan ini akan lebih kongkrit dan meyakinkan bilamana dapat didukung oleh data dan informasi yang kuantitatif secara terukur.

Opportunities (peluang) dapat diartikan sebagai kesempatan dan kemungkinan yang tersedia dan dapat dimanfaatkan untuk mendukung proses pembangunan daerah atau institusi bersangkutan. Sebagaimana telah disinggung terdahulu bahwa peluang ini adalah unsur yang datang dari luar 
(eksternal), baik dari kondisi ekonomi, sosial, aturan kebijakan dan aturan pemerintah atau karena adanya perubahan teknologi baru. Dalam analisis kondisi sosial ekonomi peluang tersebut dapat muncul dalam bentuk adanya minat masyarakat yang cukup tinggi terhadap sesuatu hal, meningkatnya daya beli masyarakat, adanya kebijakan dan aturan baru yang dapat memberikan peluang pengembangan atau karena adanya perubahan teknologi dan penemuan produk baru yang dapat mendorong timbulnya kebutuhan baru pula dan lain-lainnya. Sama denga hal terdahulu, analisis akan lebih kongkrit dan lebih tajam bilamana kesemua unsur peluang tersebut dapat dimunculkan dengan data dan informasi kuantitatif sehingga menjadi lebih terukur.

Threat (ancaman) dapat pula diartikan sebagai suatu kondisi yang datang dari luar dan dapat menimbulkan kesulitan, kendala atau tantangan yang cukup serius bagi suatu daerah atau institusi tertentu. Ancaman tersebut dapat muncul sebagai akibat kemajuan dan perubahan kondisi sosial ekonomi, perubahan kebijakan dan aturan atau karena terjadinya perubahan pandangan dan kemajuan teknologi. Sebagai contoh, dengan semakin mantapnya pelaksanaan otonomi daerah maka masing-masing daerah akan berlomba-lomba untuk mempercepat proses pembangunan daerahnya masing-masing sehingga terjadi persaingan yang semakin tajam antar daerah berkaitan.

Dengan menggunakan keempat unsur tersebut secara rinci dan jika mungkin dalam bentuk kuntitatif, maka analisis tentang kondisi sosial ekonomi daerah atau institusi bersangkutan akan semakin jelas dan kongkrit. Karena itulah analisis SWOT ini lazim pula digunakan sebagai alat untuk melakukan evaluasi diri (self evaluation) terhadap suatu institusi tertentu. Perlu dicatat disini bahwa analisis SWOT ini akan menjadi baik dan dapat dipercaya bilamana penilaian terhadap kekuatan, kelemahan, peluang dan ancaman tersebut dilakukan secara jujur tanpa ditutupi atau dinilai secara berlebihan.

Analisis SWOT lazim digunakan dalam penyusunan sebuah perencanaan, khusunya rencana strategis (Renstra). Teknik perencanaan ini menjadi populer karena dia dapat menghasilkan suatu strategi pembangunan yang lebih terarah sesuai dengan potensi yang dimiliki oleh daerah atau institusi bersangkutan. Disamping itu, dengan menggunakan teknik SWOT akan dapat pula dihasilkan program dan kegiatan yang lebih tepat untuk merebut peluang yang tersedia maupun untuk mengatasi kelemahan yang dihadapi. Penggunaan analisis SWOT akan dapat menggunakan analisis yang lebih kongkrit dan realistis sesuai dengan kondisi dan situasi yang dimiliki oleh daerah atau institusi bersangkutan. Karena itu tidaklah mengherankan bilamana analisis SWOT ini sangat populer dikalangan aperatur pemerintahan dalam penyusunan rencana pembangunan untuk suatu daerah atau institusi tertentu (Hubeis \& Najib, 2014, pp. 16-17).

Semula rencana strategis ini umumnya digunakan dalam penyusunan rencana untuk dunia usaha dimana tingkat persaingan sangat tajam. Akan tetapi karena dalam era otonomi daerah persaingan antara suatu daerah dengan daerah lainnya juga sangat tajam dalam mendorong proses pembangunan pada masing-masing daerahnya, maka belakangan ini rencana strategis ini juga sangat populer dalam menyusun rencana pembangunan untuk masing-masing dinas instansi pada tingkat daerah. Aspek lain yang juga mendorong instansi pemerintah untuk menyusun rencana strategis ini adalah karena penyusunan 
rencana ini lebih terfokus pada aspek-aspek yang bersifat strategis dan langsung mempengaruhi kinerja pembangunan dari dinas dan instansi bersangkutan.

Analisis SWOT pada dasarnya merupakan identifikasi berbagai faktor dan unsur penentu pembangunan suatu institusi secara sistematis untuk melakukan evaluasi kondisi lingkup kegiatan bersangkutan dan selanjutnya dapat pula digunakan untuk merumuskan strategi pembangunan institusi yang tepat sesuai dengan kondisi dan potensi yang dimilikinya. Dalam penerapannya, institusi yang dimaksud disini dapat berbentuk perusahaan atau instansi pemerintah. Analisis SWOT ini didasarkan pada kondisi umum institusi bersangkutan baik yang bersifat internal maupun external guna mencapai tujuan serta visi dan misi yang telah ditetapkan semula oleh para pemangku kepentingan. Kekuatan utama analisis SWOT adalah dapat melakukan evaluasi secara lebih tajam dan terarah. Kemudian analisis dapat digunakan untuk perumusan strategi pembangunan secara sistematis sesuai dengan kondisi dan lingkungan institusi bersangkutan dalam rangka menghadapi kondisi persaingan sesama institusi bersangkutan.

Unsur kekuatan dan kelemahan pada dasarnya adalah faktor internal yang berasal dari dalam daerah atau lingkup tugas (TUPOKSI) institusi tertentu. Sedangkan unsur peluang dan ancaman adalah merupakan faktor eksternal yang berasal dari luar daerah atau ruang lingkup tugas tertentu berpengaruh terhadap masa depan institusi. Pengelempokan ini perlu diperhatikan agar tidak terjadi keraguan atau kebingungan dalam menentukan aspek-aspek yang termasuk atau berkaitan dengan keempat unsur analisis SWOT tersebut.

Secara lebih spesifik, ada dua manfaat utama dari penggunaan analisis SWOT dalam penyusunan perencanaan pembangunan. Pertama, dengan menggunakan analisis SWOT pembahasan tentang kondisi umum daerah atau suatu institusi akan menjadi lebih tajam dan terarah kepada hal-hal yang berkaitan langsung dengan penyusunan perencanaan. Hal ini sangat penting artinya karena kondisi umum (existing condition) adalah merupakan dasar utama penyusunan perencanaan pembangunan. Perumusan perencanaan pembangunan akan menjadi lebih tepat dan terarah bilamana analisis tentang kondisi umum daerah juga dapat dilakukan dengan cara lebih baik dan tajam, dan demikian pula sebaliknya terjadi apabila analisis tentang kondisi umum daerah dilakukan terlalu umum dan tidak terarah.

Kedua, manfaat selanjutnya dari penggunaan analisis SWOT adalah dapatnya dirumuskan strategi pembangunan daerah sesuai dengan kondisi umum daerah dan institusi bersangkutan. Perumusan strategi pembangunan daerah menjadi lebih tajam dan terarah sesuai dengan kondisi dan potensi yang dimiliki oleh daerah dan institusi bersangkutan. Dengan demikian kemungkinan berhasilnya pelaksanaan strategi pembangunan daerah tersebut akan menjadi lebih besar.

\section{Menghasilkan Renstra}

Proses perencanaan strategis dapat memberikan hasil yang bermanfaat, yaitu memberikan kerangka kerja untuk pengembangan anggaran tahunan, alat pengembangan manajemen perencanaan, mekanisme untuk memaksa manejemen agar memikirkan jangka panjang, dan alat untuk menyejajarkan manajer dengan strategi jangka panjang. 
Meskipun perencanaan strategis mempunyai banyak manfaat, namun juga memiliki beberapa keterbatasan, yaitu selalu ada bahaya bahwa perencanaan berakhir menjadi pengisian formulir, latihan birokrasi, tanpa pemikiran strategis. Bahwa organisasi mungkin menciptakan departemen perencanaan strategis yang besar dan mendelegasikan pembuatan rencana strategis kepada para staf dari departemen tersebut. Serta perencanaan strategis adalah proses yang memakan waktu dan biaya yang mahal.

\section{Diskusi dan Revisi Renstra}

Perencanaan strategis merupakan proses memutuskan program-program yang akan dilaksanakan oleh organisasi dan perkiraan jumlah sumber daya yang akan dialokasikan ke setiap program jangka panjang selama beberapa tahun ke depan. Setelah sosialisasi, diskusi dengan tim dan melakukan revisi atas perubahan rencana strategis untuk kesempurnaan target dan capaian yang akan ditempuh berdasarkan saran dan kritikan dari tim Renstra dan pakar Renstra.

Perencanaan strategis digunakan untuk menentukan atau mewujudkan visi dan misi organisasi dan membagi-bagi sumberdaya yang diperlukan untuk mencapainya. Jadi dapat dikatakan suatu organisasi pada mulanya memiliki citacita atau tujuan akhir yang ingin dicapai dalam jangka panjang yang disebut visi, selanjutnya untuk mencapai atau mewujudkan visi organisasi yang telah ditentukan tersebut, organisasi merumuskan upaya-upaya umum yang hendak dilakukan yang disebut misi, kemudian untuk mewujutkan misi, organisasi membuat atau merumuskan upaya khusus yang dirasa paling efektif dan efisien untuk mencapai cita-cita organisasi yang disebut perencanaan strategis.

\section{SIMPULAN}

Pendidikan merupakan sebuah program yang terencana dan tersistem dengan baik. Program yang melibatkan sejumlah komponen yang bekerjasama dalam sebuah proses untuk mencapai tujuan yang diprogramkan. Sebagai sebuah program, pendidikan merupakan aktivitas sadar dan sengaja yang diarahkan untuk mencapai suatu tujuan. Berpikir sistemik (systemic thinking) adalah sebuah cara untuk memahami sistem yang kompleks dengan analisis bagian-bagian sistem tersebut untuk kemudian mengetahui pola hubungan yang terdapat didalam setiap unsur atau eleman penyusun sistem tersebut pada prinsipnya berpikir sistemik mengkombinasikan dua kemampuan berpikir yaitu, kemampuan berpikir analis dan berpikir sintesis. Perencanaan strategis adalah proses penentuan strategi dan pengalokasian sumber daya yang dimiliki organisasi untuk mencapai suatu tujuan jangka panjang. Perencanaan strategi tiap organisasi berbeda-beda namun memiliki manfaat dan tujuan yang sama yaitu mempersiapkan strategi untuk masa depan. Perencanaan strategi erat hubungannya dengan visi dan misi suatu organisasi dimana fungsinya adalah sebagai langkah spesifik untuk mewujudkan visi dan misi organisasi.

Setiap organisasi perlu melakukan suatu perencanaan dan wacana dalam setiap kegiatan organisasinya, baik dalam pengembangan organisasi, program, maupun anggarannya. Perencanaan (planning) merupakan proses dasar bagi organisasi untuk memilih sasaran dan menetapkan bagaimana cara mencapainya, sedangkan rencana ( $p l a n)$ adalah hasil dari perencanaan (planning) yang di proses oleh perencana (planner). Oleh karena itu, perusahaan 
harus menetapkan tujuan dan sasaran yang hendak dicapai sebelum melakukan prosesproses perencanaan.

Analisis SWOT lazim digunakan dalam penyusunan sebuah perencanaan, khusunya rencana strategis (Renstra). Teknik Perencanaan ini menjadi populer karena dia dapat menghasilkan suatu strategi pembangunan yang lebih terarah sesuai dengan potensi yang dimiliki oleh daerah atau institusi bersangkutan. Disamping itu, dengan menggunakan teknik SWOT akan dapat pula dihasilkan program dan kegiatan yang lebih tepat untuk merebut peluang yang tersedia maupun untuk mengatasi kelemahan yang dihadapi.

Proses perencanaan strategis dapat memberikan hasil yang bermanfaat, antara lain memberikan kerangka kerja untuk pengembangan anggaran tahunan, alat pengembangan manajemen perencanaan, mekanisme untuk memaksa manejemen agar memikirkan jangka panjang dan alat untuk menyejajarkan manajer dengan strategi jangka panjang.

\section{REFERENSI}

Aminullah, E. (2004). Berpikir Sistemik. PPM.

Handoko, T. H. (2009). Manajemen. BPFE Yogyakarta.

Hubeis, M., \& Najib, M. (2014). Manajemen Strategik (Dalam Pengembangan Daya Saing Organisasi). Elex Media Komputindo.

James, L. (1983). Long range and Short Range Planning for Education. Allyn and Bacon, Inc.

Kodrat, D. S. (2009). Manajemen Strategi: Membangun Keunggulan Bersaing Era Global di Indonesia Berbasis Kewirausahaan. Graha Ilmu.

Luxton, A. (2005). Strategic Planning in Higher Education. GCDE.

Mintzberg, H. (1993). Structure in Fives: Designing Effective Organization. Englewood Cliffs. Prentice Hall International.

Nurhapna, \& Haksama, S. (2014). Pengaruh Perencanaan Strategis Terhadap Kinerja Di Rumah Sakit. Jurnal Administrasi Kesehatan Indonesia, 2(2), 91-100. http://journal.unair.ac.id/download-fullpapersjaki4fced9bea5full.pdf

Pearce, J. A., \& Robinson, R. B. (2009). Manajemen Strategis: Formulasi, Implementasi Dan Pengendalian. Salemba Empat.

Purwanto, P. (2009). Evaluasi Hasil Belajar. Pustaka Pelajar.

Rangkuti, F. (1997). Analisis SWOT Teknik Membedah Kasus Bisnis. PT. Gramedia Pustaka Utama.

Rowley, D. J., Lujan, H. D., \& Dolonce, M. G. (1997). Strategic Change in Collages and Universities: Planning to Survive and Prosper. Jossey-Bass Publishers.

Sarbini, S. (2011). Perencanaan Pendidikan. CV. Pustaka Setia.

Solihin, I. (2012). Manajemen Strategi. Erlangga.

Stainer, G. A., Miner, J. B., \& Gray, E. R. (1997). Management Policy and Strategy: Text, Reading and Cases. Macmillan.

Subagyo, P. J. (2015). Metode Penelitian dalam Teori dan Praktek. Rineka Cipta.

Utsman, K., \& Nadhirin, N. (2008). Perencanaan Pendidikan. STAIN Kudus. 